\title{
Incidence of Type 1 (insulin-dependent) diabetes mellitus in Catalonia, Spain
}

\author{
A. Goday ${ }^{1}$, C. Castell ${ }^{2}$, R.Tresserras ${ }^{2}$, J. Canela $^{3}$, J.L.Taberner ${ }^{2}$, G. Lloveras ${ }^{2}$ \\ and the Catalan Epidemiology Diabetes Study Group* \\ ${ }^{1}$ Servei d'Endocrinologia, Hospital de L'Esperança, Barcelona, Comissió d'Epidemiologia, Consell Assessor sobre la Diabetis a Catalunya, \\ 2 Consell Assessor sobre la Diabetis a Catalunya, Direcció General de Salut Publica, Departament de Sanitat i Seguretat Social, \\ Generalitat de Catalunya, \\ ${ }^{3}$ Department of Public Health and Health Legislation, Health Science Division, University of Barcelona, Spain
}

\begin{abstract}
Summary. The incidence of Type 1 (insulin-dependent) diabetes mellitus was prospectively evaluated in Catalonia, Spain in patients up to 30 years of age during the period 1987-1990. The population at risk (0-29 years) consisted of 2,690,394 inhabitants (total population of Catalonia $5,978,638)$. All the cases were independently identified from four sources: endocrinologists, sales of blood glucose monitors and insulin pen injectors, diabetes societies and diabetic summer camps. The degree of ascertainment was $90.1 \%$. The overall observed incidence rate was 10.7 per 100,000 per year, being 11.5 per 100,000 per year in the $0-14$ age group. The incidence in males ( 12.0 per 100,000 per year) was higher than in females ( 9.3 per 100,000 per year), with a male/female ratio of 1.36/l. The sex differences were only present in cases over 14 years of age. Age specific incidence rates per 100,000 per
\end{abstract}

year were 4.4 (confidence interval $95 \%: 3.2-5.7$ ) in the age group 0-4, 9.9 (8.5-11.4) in 5-9, $17.5(15.7-19.4)$ in 10-14, $11.4(9.9-13.0)$ in 15-19, 11.3 (9.7-13.0) in 20-24 and 8.5 (7.29.9 ) in $25-29$. There was a seasonal onset pattern, with the highest incidence in winter (December-February). We conclude that the incidence of Type 1 diabetes observed in Catalonia during the period 1987-1990 is higher than that recently reported in other Mediterranean countries. This study offers the first standardized data on Type 1 diabetes incidence in Catalonia, including cases up to 30 years, and contributes to the knowledge of the epidemiology of diabetes in South Europe.

Key words: Type 1 (insulin-dependent) diabetes mellitus, incidence, epidemiology, seasonality, Catalonia.
The incidence of Type 1 (insulin-dependent) diabetes mellitus in different countries has shown pronounced geographical variations. Such differences have been reported in Europe, generating the concept of a north to south gradient in the incidence of the disease [1]. North European countries have high rates of new cases [2-6], Finland having the highest known incidence of Type 1 diabetes in the world [5]. The incidence decreases in Central European countries [7-9], and also seems to be lower in the south of Europe [10,11]. Nevertheless this gradient was postulated with the few epidemiological data available 4 years ago. Therefore, the characterization of the incidence of Type 1 diabetes in different countries will provide the basis for the study of the role of genetic and environmental factors in the aetiology and pathogenesis of the disease.

Little information has been available about diabetes incidence in Mediterranean countries $[10,11]$, and until the last 2 years no data existed regarding populations of Spain. In 1988, Millan et al. reported preliminary data on

* See list of participants. the incidence of Type 1 diabetes in Terrassa [12], a city of 160,000 inhabitants near Barcelona. In addition, SerranoRios et al. recently reported data concerning newly-diagnosed cases under the age of 15 years in the community of Madrid [13].

In 1986, a programme was initiated in Catalonia to accurately and prospectively document the incidence data of Type 1 diabetes for individuals under the age of 30 years during a 4-year period.

\section{Subjects and methods}

This is a prospective incidence study of Type 1 diabetes with onset before the 30 th birthday. The recruitment assumed complete ascertainment within Catalonia, a geographically and demographically well-defined region, with an independent health service.

\section{Population base}

Catalonia is an autonomous community of Spain on the Mediterranean coast, in the north-east of the Iberian peninsula, separated from France by the Pyrenees Mountains. The area is 31,980 square 
$\mathrm{km}$. Information concerning the population base was received from the 1986 General Census. The total population of Catalonia is $5,978,638$ and the at risk population for diabetes in the $0-29$ year age group is $2,690,394(0-14: 1,295,763,15-19: 1,394,631)$. Catalonia represents $15.5 \%$ of the Spanish population.

\section{Case definition}

All diabetic patients diagnosed between 1 January 1987 and 31 December 1990, who were under 30 years at the time of diagnosis were included in the study. They had to be living in Catalonia for at least 6 months prior to diagnosis. Diabetes was defined according to the World Health Organization Criteria [14]. Type 1 diabetes was defined as the presence of ketonuria, and the need for permanent insulin therapy. All of the reported cases were on insulin treatment. A strict classification by e.g. tissue typing, C-peptide levels, islet cell antibodies, was not performed in all the cases. Nevertheless, most of the endocrinology, diabetes and paediatric units of Catalonia perform, at diagnosis, a glucagon test measuring C-peptide levels, islet cell antibodies and insulin autoantibodies. Using this clinical and laboratory data the physician can diagnose a case as Type 1 diabetes. Therefore, the assumption was made that the large majority of cases were indeed Type 1 diabetes. The date of first insulin injection was used as the date of inclusion in the study. Secondary diabetes and maturity onset diabetes of the young (MODY) were excluded.

\section{Case ascertainment}

The primary source of ascertainment was a contact system with all the paediatricians and endocrinologists/diabetologists of the diabetes care network of Catalonia, including all the hospital endocrinology, diabetes and paediatric Units and also the outpatient endocrinologists of the Public Health Service. The Catalan Health Service ("Servei Catala de la Salut") covers $99 \%$ of the population of Catalonia. The remainder is attended to by hospitals or private practices. The prescription of insulin, syringes and glucose monitoring strips is given free of charge, paid for by the Health Service, but the patient must visit the endocrinologist every 3 months to obtain the official prescriptions which are presented to the chemist. All physicians who might be treating Type 1 diabetic patients in Catalonia were included in a mailing list. At 3-month intervals, the local coordinators sent a letter asking for new cases of Type 1 diabetes, along with forms and pre-stamped envelopes to all the participants. If a physician had not observed any case during the study period, he returned the questionnaire with "No case seen during the period" on it. At the end of the year, a list of all new Type 1 diabetes cases reported was sent to all the participants in the study so they could double check the patient information.

The methods used for validation were the affiliation to diabetes societies, the summer camps for diabetic children and adolescents and the sales of capillary blood glucose monitors and insulin pen injectors. There are 11 diabetes societies across the country, co-ordinated by a Catalan federation. On the other hand, the summer camps for diabetic children and adolescents have been organized in Catalonia since 1979 with a high degree of participation. With the collaboration of commercial laboratories, all new Type 1 diabetic patients fulfilling case-definition criteria could obtain an insulin pen or a blood glucose monitor later in order to complete a questionnaire. The correctness of the data of the questionnaires was carefully checked.

\section{Collection of data}

For every case recruited, the following data were collected: personal identification code, date and place of birth, sex, address, age, date of clinical diagnosis (first insulin injection), duration of symptoms, hospitalization at diagnosis, ketosis and blood glucose level at diagnosis.

\section{Statistical analysis}

For the incidence of Type 1 diabetes $95 \%$ confidence intervals (C. I.) were estimated assuming a Poisson distribution (15). To establish the completeness of ascertainment the capture-recapture method described by Bishop et al. was employed (16). Briefly, the method was calculated as follows:

Completeness of source $\mathrm{A}=\mathrm{Ca}=(\mathrm{a}+\mathrm{c}) / \mathrm{N}$

Completeness of source $\mathrm{B}=\mathrm{Cb}=(\mathrm{a}+\mathrm{b}) / \mathrm{N}$

$\mathrm{Ca}=\mathrm{a} /(\mathrm{a}+\mathrm{b}) \quad \mathrm{Cb}=\mathrm{a} /(\mathrm{a}+\mathrm{c})$

Probability of escaping both sources $=\mathrm{X} / \mathrm{N}=(1-\mathrm{Ca})(1-\mathrm{Cb})$

Combined completeness of ascertainment source $\mathrm{A}$ and $\mathrm{B}=$ $\mathrm{Cab}(\%)=(1-\mathrm{X} / \mathrm{N}) \times 100$

a: new cases with primary source and also secondary source b: new cases with secondary source but not with primary source c: new cases with primary source but not with secondary source $\mathrm{x}$ : unknown number of cases not registered in any source

Completeness of ascertainment are presented as percentages. Incidence rates were calculated with the observed cases (observed incidence). The seasonal variation was evaluated using the method described by Edwards [17].

\section{Results}

\section{Incidence rate}

During the period January 1987 - December 1990, 1,154 new cases of Type 1 diabetes were identified. The overall observed incidence rate under age 30 years was 10.7 per 100,000 per year $(95 \%$ C.I.: $10.1-11.3$ per 100,000 per year). Rates were 12.0 (95\% C.I. 11.4-13.0) among males and $9.3(8.5-10.2)$ among females. Thus, among the whole group more cases were observed in males than in females, with a sex ratio of 1.36 , which is significantly different

Table 1. Age-specific observed incidence rates (per 100,000 personyears) of Type 1 (insulin-dependent) diabetes for residents of Catalonia 1987-1990

\begin{tabular}{|c|c|c|c|c|c|c|}
\hline \multirow{2}{*}{$\begin{array}{l}\text { Age } \\
\text { group }\end{array}$} & \multicolumn{2}{|l|}{ Males } & \multicolumn{2}{|c|}{ Females } & \multicolumn{2}{|l|}{ Total } \\
\hline & $\begin{array}{l}\text { Cases } \\
(n)\end{array}$ & $\begin{array}{l}\text { Age-spe- } \\
\text { cific inci- } \\
\text { dence rate } \\
(95 \% \text { C.I.) }\end{array}$ & $\begin{array}{l}\text { Cases } \\
(n)\end{array}$ & $\begin{array}{l}\text { Age-spe- } \\
\text { cific inci- } \\
\text { dence rate } \\
(95 \% \text { C.I.) }\end{array}$ & $\begin{array}{l}\text { Cases } \\
(n)\end{array}$ & $\begin{array}{l}\text { Age-spe- } \\
\text { cific inci- } \\
\text { dence rate } \\
\text { (95\% C.I.) }\end{array}$ \\
\hline $0-4$ & 32 & $\begin{array}{l}4.6 \\
(3.2-6.6)\end{array}$ & 27 & $\begin{array}{l}4.1 \\
(2.7-6.1)\end{array}$ & 59 & $\begin{array}{l}4.4 \\
(3.2-5.7)\end{array}$ \\
\hline $5-9$ & 93 & $\begin{array}{l}9.9 \\
(8.0-12.4)\end{array}$ & 88 & $\begin{array}{l}9.9 \\
(7.9-12.2)\end{array}$ & 181 & $\begin{array}{l}9.9 \\
(8.5-11.4)\end{array}$ \\
\hline $10-14$ & 180 & $\begin{array}{l}17.1 \\
(14.7-19.8)\end{array}$ & 177 & $\begin{array}{l}17.9 \\
(15.4-20.8)\end{array}$ & 357 & $\begin{array}{l}17.5 \\
(15.7-19.4)\end{array}$ \\
\hline $15-19$ & 138 & $\begin{array}{l}13.9 \\
(11.7-16.4)\end{array}$ & 83 & $\begin{array}{l}8.8 \\
(7.0-10.9)\end{array}$ & 221 & $\begin{array}{l}11.4 \\
(9.9-13.0)\end{array}$ \\
\hline $20-24$ & 119 & $\begin{array}{l}12.5 \\
(10.3-14.9)\end{array}$ & 66 & $\begin{array}{l}7.1 \\
(5.5-9.1)\end{array}$ & 185 & $\begin{array}{l}11.3 \\
(9.7-13.0)\end{array}$ \\
\hline $25-29$ & 100 & $\begin{array}{l}11.2 \\
(9.1-13.7)\end{array}$ & 51 & $\begin{array}{l}5.7 \\
(4.2-7.5)\end{array}$ & 151 & $\begin{array}{l}8.5 \\
(7.2-9.9)\end{array}$ \\
\hline $0-14$ & 305 & $\begin{array}{l}11.4 \\
(10.1-12.7)\end{array}$ & 292 & $\begin{array}{l}11.6 \\
(10.3-13.0)\end{array}$ & 597 & $\begin{array}{l}11.5 \\
(10.6-12.4)\end{array}$ \\
\hline $15-29$ & 357 & $\begin{array}{l}12.6 \\
(11.3-14.0)\end{array}$ & 200 & $\begin{array}{l}7.2 \\
(6.2-8.3)\end{array}$ & 557 & $\begin{array}{l}9.9 \\
(9.8-10.8)\end{array}$ \\
\hline $0-29$ & 662 & $\begin{array}{l}12.0 \\
(11.4-13.0)\end{array}$ & 492 & $\begin{array}{l}9.3 \\
(8.5-10.2)\end{array}$ & 1154 & $\begin{array}{l}10.7 \\
(10.1-11.3)\end{array}$ \\
\hline
\end{tabular}




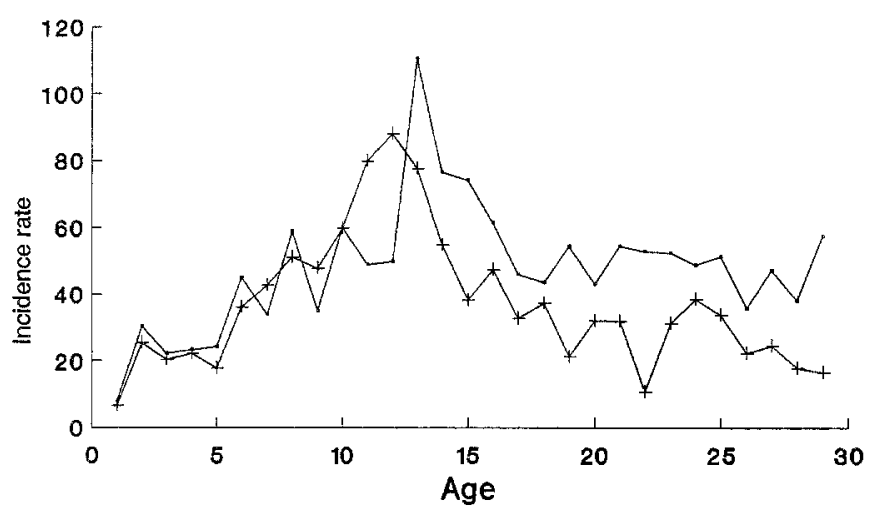

Fig. 1. Occurrence of newly-diagnosed Type 1 (insulin-dependent) diabetic cases in Catalonia 1987-1990 with respect to age at diagnosis. *, Males; +, Females

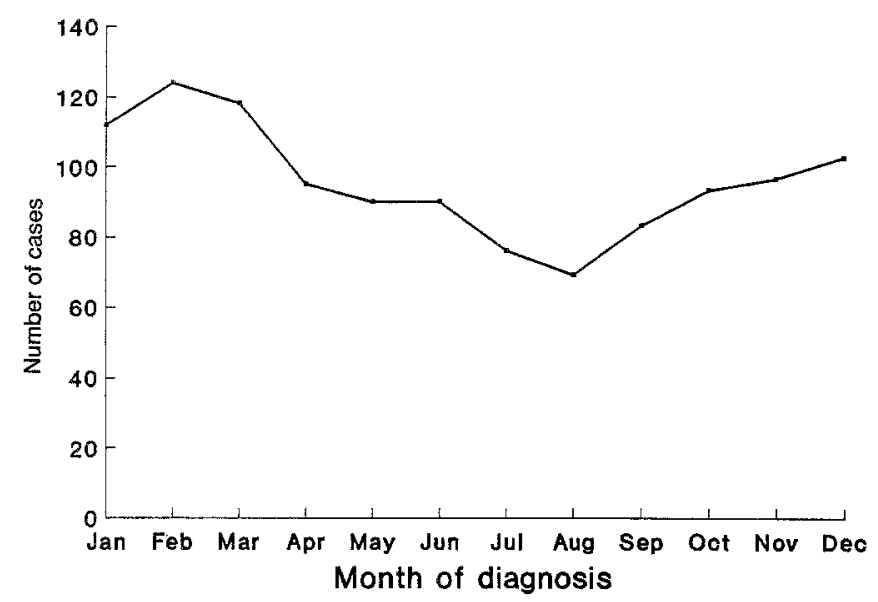

Fig. 2. Occurrence of newly-diagnosed Type 1 (insulin-dependent) diabetic cases in Catalonia 1987-1990 with respect to the month of diagnosis

from the general population (male/ female ratio 1.04) (Chi square $p<0.001$ ). Within age groups, these differences were only observed in newly-diagnosed cases older than 14 years $(15-19$ years $p<0.01,20-24$ years $p<0.01,25-$ 29 years $p<0.005,15-29$ years $p<0.0001$ ) (Chi square between age groups $0-14$ and 15-29 and sex was 19.4, $p<0.0001$ ).

Table 1 shows age- and sex-specific incidence rates for Type 1 diabetes in Catalonia. Significant variations in incidence were observed with age, children ( $0-4$ years) exhibiting the lowest rate (4.4 per 100,000 per year, $95 \%$ C. I. $3.2-5.7)$. A steadily increasing gradient with age to peak incidence in the age group 10-14 years was observed (17.5 per 100,000 per year, $95 \%$ C.I. $15.7-19.4)$. Within the group the peak incidence of Type 1 diabetes occurred at 13 years of age. The mean age for all cases was $15.3 \pm 6.9$ (mean $\pm \mathrm{SD}$ ), being higher in males than in females $(16.0 \pm 7.0$ vs $14.3 \pm 6.6)$ (Fig. 1).

No significant annual differences were observed in the incidence of the disease during the 4 years of the study, in either the whole group (Table 2) or in the different age groups (Poisson distribution).

Variation of incidence according to month of diagnosis was confirmed. Significantly more cases were diagnosed in the autumn and winter than in the summer every year (Edward's Test, $p<0.05$ ) (Fig. 2).

\section{Completeness of ascertainment}

Table 3 shows the basic data for estimation of completeness of ascertainment. Among the 1,154 cases, 1,122 were obtained from the contact system with endocrinologists, diabetologists and paediatricians. The ascertainment was based on this group. The summer camps for diabetic children identified 13 additional cases, the diabetes associations 20 and the delivery of blood glucose monitors and insulin pen injectors 1 , providing a degree of ascertainment of $87.5 \%$ with the primary source, and $8.2 \%$ for summer camps, $12.0 \%$ for diabetes societies and $7.2 \%$ for blood glucose monitors and pen injectors. No clinical features identified these cases as a group. The overall completeness of ascertainment of the Catalan registry was estimated to be $90.1 \%$.

\section{Discussion}

The present work represents the first validated study of Type 1 diabetes incidence in Catalonia, and the first among cases 0-29 years carried out in Spain. Our data contributes to the knowledge of diabetes incidence in $\mathrm{Me}$ diterranean countries, an area which up to now has been

Table 2. Annual incidence (per 100,000), number of cases and the 95\% Poisson confidence interval (C.I.) of Type 1 (insulin-dependent) diabetes in Catalonia in patients aged less than 30 years at diagnosis during 1987 to 1990

\begin{tabular}{lllll}
\hline Year & 1987 & 1988 & 1989 & 1990 \\
\hline Males & & & & \\
$n$ & 164 & 149 & 169 & 180 \\
Incidence & 11.9 & 10.8 & 12.3 & 13.1 \\
(95\% C. I.) & $(10.1-13.9)$ & $(9.2-12.7)$ & $(10.5-14.3)$ & $(11.2-15.1)$ \\
Females & & & & \\
$n$ & 106 & 129 & 125 & 132 \\
Incidence & 8.0 & 9.8 & 9.4 & 10.0 \\
(95\% C.I.) & $(6.5-9.7)$ & $(8.2-11.6)$ & $(7.9-11.3)$ & $(8.3-11.8)$ \\
Total & & & & \\
$n$ & 270 & 278 & 294 & 312 \\
Incidence & 10.0 & 10.3 & 10.9 & 11.5 \\
(95\% C.I.) & $(8.8-11.3)$ & $(9.1-11.6)$ & $(9.7-12.3)$ & $(10.4-13.0)$ \\
\hline
\end{tabular}

Table 3. Number of cases and completeness of case ascertainment for primary source (physicians) and secondary sources in Catalonia 1987-1990. Total observed cases $=($ primary + secondary $)-$ both

\begin{tabular}{lrrrrr}
\hline Year & \multicolumn{5}{l}{ No. of Cases (\% of total estimated) } \\
\cline { 2 - 6 } & Primary & Secondary Both & \multicolumn{1}{l}{$\begin{array}{l}\text { Total } \\
\text { observed } \\
\text { cases }\end{array}$} & $\begin{array}{l}\text { Total } \\
\text { estimated } \\
\text { cases }\end{array}$ \\
\hline 1987 & $260(82.2)$ & $68(22.1)$ & $58(18.3)$ & $270(85.9)$ & 316 \\
1988 & $266(80.3)$ & $60(18.1)$ & $48(14.5)$ & $278(83.4)$ & 331 \\
1989 & $286(91.1)$ & $89(28.2)$ & $81(25.7)$ & $294(93.6)$ & 315 \\
1990 & $310(97.4)$ & $83(26.1)$ & $81(25.4)$ & $312(98.1)$ & 318 \\
$87-90$ & $1122(87.6)$ & $300(23.4)$ & $268(20.9)$ & $1154(90.1)$ & 1280 \\
\hline
\end{tabular}


lacking in epidemiological data. The great number of cases gives a narrow confidence interval for all the results obtained.

The observed incidence of Type 1 diabetes in Catalonia, 10.7 per 100,000 per year in $0-29$ years, 11.5 per 100,000 per year in $0-14$ years, was intermediate between the high rates reported in Northern European countries such as Finland (5), Sweden (4), Norway (3) and Denmark (6), and in England (18) or Scotland (19), and the lower incidence of some Southern European countries such as Israel (10) France (9), and Italy (Turin) (11) but similar to those reported in Luxembourg (8), the Netherlands (7), Austria (20), Malta (21) and Madrid (13).

The male excess was only present in the 15-29 age group. Interestingly, these differences in sex above 14 years of age have been observed in some of the few north European studies which included the 15-29 age group, such as those from Finland (5), Denmark (6), Sweden (25) and Norway (23). In females, the peak age at onset of the disease tends to be 1.5 years earlier than in males, as previously reported, the peak incidence occurring in the 10-14 year age group. We did not find any possible cause of under-reported cases among females in the 15-29 age group.

Some epidemiological studies have shown temporal changes in the incidence of Type 1 diabetes in the last decade in Poland (24) Norway (3), and Sweden $(4,25)$. No secular trends were observed in incidence rates in Catalonia during the 4-year observation period (1987-1990), either in the whole group or when controlling for age or sex. Nevertheless, although the duration of the study is probably not long enough to observe these changes, it gives us the background information to detect a possible unexpected change in the incidence rates in the coming years.

It seems clear that the completeness of ascertainment has improved during the study period, from 85.9 in 1987 to 98.1 in 1990. This could be due to under-reporting in the first year of the study, when some physicians were not used to declaring the cases. On the other hand, the inclusion of this study in EURODIAB Subarea A increased the physicians motivation to participate in a European collaborative study.

Our study gives an incidence, for the 0-14 age group, similar to that recently reported in the community of Madrid by Serrano-Rios et al. [13], the only previously reported validated data from Spain. The major differences between the two studies are the age groups included (0-29 in Catalonia vs 0-14 in Madrid) and the geographical area and climate (Mediterranean in Catalonia; continental in the centre of the Iberian peninsula in Madrid). The methodology was similar, using the capture-recapture method to estimate the completeness of ascertainment and the standardized criteria for registries established by LaPorte [27], the present study being prospective and not retrospective. The incidence observed in Catalonia is higher than that previously expected. Therefore, our data do not support the hypothesis that a latitudinal (northsouth) gradient may be of major importance as an explanation of the wide geographical variations in the incidence of diabetes observed in Europe [1]. We have no hypo- thesis for this observed geographical variation. The wide spectrum of rates observed in Europe and world wide demonstrates the need for collaborative international studies on the epidemiology of Type 1 diabetes. The knowledge of the incidence rates in Catalonia is the basic contribution to study the role that genetic and environmental factors may play in this variation.

Acknowledgements. This work was supported by the Consell Assessor sobre la Diabetis a Catalunya, Departament de Sanitat i Seguretat Social de la Generalitat de Catalunya. This study was included as a member of the EURODIAB Subarea A programme during the period 1989-1990. The authors wish to thank Drs. A. Green and E. Gale, project leaders of the study, for their support, and also to all the participants in EURODIAB. Alberto Goday was supported by the World Health Organization, International Diabetes Federation and British Diabetes Association to participate in the Fourth Cambridge Seminar on Epidemiology of Diabetes. The authors wish to thank Dr. R. LaPorte, Dr. J. Dorman and Dr. C.Moy of the World Health Organization Collaborating Center for Diabetes Registries in Pittsburgh, Pennsylvania, USA, and J. M. Adell of the Federacio Catalana de Associacions de Diabetics.

Catalan Diabetes Epidemiology Study Group. This study represents a collaborative effort between all professionals working with Type 1 (insulin-dependent) diabetes in Catalonia, involving 70 different centres. The following individuals have contributed to the foundation of the Catalan Epidemiology Diabetes Study Group:

E. Aguadé, JM. Albarran, X. Allué, M. Aliart, J. Anglada, J. Arroyo, M. Bergua, JM.Calvet, J.F.Cano, R.Carrasco, A. Carrascosa, C. Castell, R. Clivillé, R. Corrales, B. Costa, M. Estruch, A. Famades, A. Felip, M.Fernandez-Castañer, D. Figuerola, X. Freixas, F. Gallo, A.Garcia-Rico, A.Goday, R.Gomis, A.Guarro, M.Gussinyé, A. Gutierrez, G.Hollenberg, L.Ibañez, F.Iniesta, A.de Leiva, T. Lezaun, G.Lloveras, J. Lopez Batllori, J. Marco, A. Martinez-Roig, I. Martinez, JR.Masoliver, D.Mauricio, J.Mayos, MT.Mengotti, J.Mesa, T.Micaló, M.Millan, E.Montaña, R.Nosas, A.Novials, A. Nubiola, M.Olesti, A.Palaudaries, C.Pavia, A.Perez, C.Perez, JM.Pla, M.Porta, G.Prat, M.Prat, J.Querol, HO.Rajmil, I.Recas, JL. Reverter, W. Ricart, L.Riu, J.Rodriguez-Hierro, M. Roqueta, R.Rosell, MD.Salcedo, A. Sanmarti, T.Sansa, JM.Sans-Mallafré, P.Sardá, A.Sarto, J.Soler, M. Soler, E.Subiracs, R. Torras, P.Utges, J. Vendrell, E. Vicens-Calvet, J. Vidal-Bota, J. Viguera, L. Vila, M. Vila, E. Vilardell, C. Vilaseca, D. Yeste, V. Yetano.

\section{References}

1. Diabetes Epidemiology Research International Group (1988) Geographic patterns of childhood insulin-dependent diabetes mellitus. Diabetes 37: 1113-1119

2. Christian B, Åkerblom H, Joner J, Dahlquist G, Ludvigsson J, Nerup J (1981) Incidence of childhood insulin-dependent diabetes mellitus in Denmark, Finland, Norway and Sweden. Acta Endocrinol 245: 68-80

3. Joner G, Søvik O (1989) Increasing incidence of diabetes mellitus in Norwegian children 0-14 years of age 1973-1982. Diabetologia 32: 79-83

4. Dahlquist G, Blom L, Holmgren G et al. (1985) The epidemiology of diabetes in Swedish children 0-14 years - a six-year prospective study. Diabetologia 28: 802-808

5. Reunanen A, Åkerblom HK, Kaar ML (1982) Prevalence and ten-year (1970-1979) incidence of insulin-dependent diabetes mellitus in children and adolescents in Finland. Acta Paediatr Scand 71:893-899

6. Christau B, Kromann H, Ortved-Andersen O et al. (1977) Incidence, seasonal and geographical patterns of juvenile-onset insulin-dependent diabetes mellitus in Denmark. Diabetologia 13: 281-284 
7. Vaandrager GJ, Bruining GJ, Veenholf FJ, Drayer NM (1984) Incidence of childhood diabetes in the Netherlands: a decrease from north to south over North-Western Europe? Diabetologia 27: 203-206

8. de Beaufort CE, Michel G, Glaesner G (1988) The incidence of Type 1 (insulin-dependent) diabetes mellitus in subjects aged 0-19 years in Luxembourg: a retrospective study from 1977 to 1986. Diabetologia 31: 758-761

9. Levy-Marchal C, Papoz L, de Beaufort C et al. (1990) Incidence of juvenile Type 1 (insulin-dependent) diabetes mellitus in France. Diabetologia 33: 465-469

10. Laron Z, Karp M, Modan M (1985) The incidence of insulindependent diabetes mellitus in Israeli children and adolescents $0-20$ years of age: a retrospective study, 1975-80. Diab Care 8: 24-28

11. Bruno G, Merletti F, Pisu E, Pastore G, Marengo C, Pagano G (1990) Incidence of IDDM during 1984-1986 in population aged $<30$ yr residents in Turin, Italy. Diab Care 13: 1051-1056

12. Millan Guasch MM, Anglada J, Arroyo J et al. (1988) Epidemiology of Type 1 (insulin-dependent) diabetes in Terrassa (160, 106 inhabitants), Barcelona: its correlation with ongoing viral infections in the community. Diabetologia 31:522 A (Abstract)

13. Serrano-Rios M, Moy CS, Martin Serrano R et al. (1990) Incidence of Type 1 (insulin-dependent) diabetes mellitus in subjects 0-14 years of age in the Comunidad of Madrid, Spain. Diabetologia 33: $422-424$

14. Expert Committee On Diabetes Mellitus (1980) World Health Organization. WHO Technical report series no. 616

15. Lilienfeld AM, Lilienfeld DE (1980) Foundations of epidemiology. Oxford University Press, Oxford, pp 336-338

16. Bishop YMM, Fienberg SE, Holland PW (1974) Discrete multivariate analysis: theory and practice. MIT Press, Massachusetts, pp 231-233

17. Edwards JH (1961) The recognition and estimation of cyclic trends. Ann Hum Genet 25: 83-87

18. Bingley PJ, Gale EAM (1989) Incidence of insulin dependent diabetes in England: a study of the Oxford region, 1985-6. Br Med J 298: 558-560
19. Waugh NR (1986) Insulin dependent diabetes in a Scottish region: incidence and urban/rural differences. J Epidemiol Community Health 40: 240-243

20. Schober E, Frisch H (1988) Incidence of childhood diabetes mellitus in Austria 1979-1984. Acta Ped Scand 77: 299-302

21. Schranz AG, Prikatsky V (1989) Type 1 diabetes in the Maltese Islands. Diab Med 6: 228-231

22. Östman J, Arnqvist H, Blohme G et al. (1986) Epidemiology of diabetes mellitus in Sweden. Acta Med Scand 220:437-445

23. Joner G, Søvik O (1991) The incidence of Type 1 (insulin-dependent) diabetes mellitus 15-29 years in Norway 1978-1982. Diabetologia 34: 271-274

24. Rewers M, Laporte R, Walczac M et al. (1987) Apparent epidemic of insulin-dependent diabetes mellitus in Midwestern Poland. Diabetes 36: 106-113

25. Nystrom L, Dahlquist G, Rewers M, Wall S (1990) The Swedish Childhood Diabetes Study. An analysis of the temporal variation in diabetes incidence 1978-1987. Int J Epidemiol 19: 141-146

26. Tuomilehto J, Rewers M, Reunanen A et al. (1991) Increasing trend in Type 1 (insulin-dependent) diabetes mellitus in childhood in Finland. Analysis of age, calendar time and birth cohort effects during 1965 to 1984 . Diabetologia $34: 282-287$

27. Laporte RE, Tajima N, Åkerblom HK et al. (1985) Geographic differences in the risk of insulin-dependent diabetes mellitus: the importance of registries. Diab Care 8 [Suppl 1]: 101-107

Received: 23 July 1991

and in revised form: 6 November 1991

Dr. C. Castell

Consell Assessor Sobre la Diabetis a Catalunya

Departament de Sanitat i Seguretat Social

Travessera de les Corts, 131-159

E-08028 Barcelona

Spain 